\title{
Translation of Civic Pedagogical Tactics to Critically Produce Public Spaces in Amman
}

\author{
Amro Yaghi \\ University of Sheffield, United Kingdom \\ School of Architecture \\ aaayaghil@sheffield.ac.uk
}

\begin{abstract}
This paper asks how can we re-think and critically produce alternative 'public' spaces through translating forms of civic pedagogical tactics in Amman? Our neoliberal contemporary cities and political agendas, with its Arabic versions, have produced socially, spatially polarised and depoliticised spaces. In fact, what we inhabit today are spaces that are pseudo public. Those spaces prompt critiquing the role of the architects, practitioners and architecture educators to intervene, mediate and response collectively. Trying to form a resistance to this problem, the responding approach is informed by reviewing and critiquing how architectural pedagogies are performed in Jordan, focusing on evaluating their civic engagement and the political and neoliberal influence. The paper then moves to focus on key relevant pedagogical models with envisioning the action plan that are adopted and tailored to the specific cultural, political and social context of Amman.

This paper framework will start reflections from some critical pedagogical theories to evaluate and critique the current architectural pedagogical approaches in Amman-Jordan contexts and analysing the various actants such as political policies, civic interventions and processes that affect architecture education. Furthermore, it generates some important lessons and reflections from practices, such as the interventions used by Romanian architects in the 1980s, Pseudo Public Space Studio-UK, live projects-UK, triggering and resisting the challenges on civic practices. The study will conclude by proposing methodological framework for translating civic pedagogical tactics that prompt to provoke and draw the public attention towards the right to the city and its space, while resisting the challenges that are facing the context of AmmanJordan. The process of translation is adopted and tailored to Amman-Jordan context, rather than imported and colonised. These tactics opened up possibilities and generated a new and alternative form of publicness, as well as a resilient and resistant community.
\end{abstract}

Keywords: public space, pseudo-public, alternative publicness, performativity, right to the city, civic pedagogy, tactics

To cite this article:

Yaghi, A. (2020). Translation of Civic Pedagogical Tactics to Critically Produce Public Spaces in Amman, The Journal of Public Space, 5(I), 37-50, DOI 10.3289I/jps.v5il.1250

This article has been double blind peer reviewed and accepted for publication in The Journal of Public Space.

(c) (1) $\$$ Th $^{\text {This }}$ work is licensed under a Creative Commons Attribution - Non Commercial 4.0 International License https://creativecommons.org/licenses/by-nc/4.0/ 


\section{Introduction}

'Public' spaces are suffering from neoliberal policies and practices which control and regulate the meaning of public space by whom can use it and how. Metropolitan cities in the Arabic region, including Amman, are taking Dubai, United Arab Emirates, and Qatar as role model. Yaghi et al (2019) argued convincingly how neoliberal practices and political policies and agendas in the Arabic region are echoed in shifting the meaning of public space from open to all to pseudo public.

Therefore, there is an urgent necessity, especially in the Arabic region, for exploring pedagogical forms of potential resistance that produces alternatives spaces that deems public. "We cannot make our claim as seekers after justice if we advocate knowledge only of and about ourselves. Our model for academic freedom should therefore be the migrant or the traveller: for if, in the real world outside the academy, we must be ourselves and only ourselves, inside the academy we should be able to discover and travel among other selves, other identities, other varieties of the human adventure." (Said, 1994). This paper focuses on drawing such potential through identifying key resistance 'tactics'. The study borrows the term tactics from De Certeau (1988), which can be defined as the tools for the powerless (ordinary people) in challenging situations. This study would argue that tactics can be in different forms including performative and civic pedagogic practice. Tactics here focuses on what Lefebvrian 'lived space'; where the dialectic relationship between the spatial and the social produces this reappropriation within the lived space. De Certeau (1988) describes such processes as "form of resistance to capitalist consumption", whereas envisioning the desired alternatives can occur through the questioning and imagining processes.

The notion of resistance that are inherited within our everyday life experienced mirrors Soja's socio-spatial dialectic, which considers spaces as active rather than statics and constantly constructing social and spatial relations. Such arguments open up possibilities for alternative practices to catalyse social and political change (Massey, 2007; Rendell 2006). These alternative practices manifest shifting the focus from physical objects to focus on the everyday experiences as forms of resistance to the dominant powers (de Cauter et al, 20I I; Massy, 2005). This has been manifested in different forms of resistance from Artists and architects during revelations, social and political protests and movements, such as the Arab spring and Occupy.

Based on practice-led research at Sheffield School of Architecture, which included performative intervening and mediating processes, it found out that higher educational institutions have the civic potential and desire to become the bridge and platform for alternative forms of resistance and spaces that deems public. Ideally, pedagogy can be the tool for social change. However, it is important to consider that such processes should always be an on-going process that should continuously evolve according to inhabitants' needs and other challenges.

Drawing from De Certeau's (1988) possibilities and Lefebvre's (I99I) notion of the social production of space, this paper puts forward visions towards civic pedagogic and performative spatial practice which is political. It performs and provokes the civic rights to question, speak out, re-claim and perhaps co-produce alternative spaces in their city. The desire of putting forward such practice, however, needs tactics, actors, agencies and activators.

This paper puts forward a vision in the way which architectural academics can become the activators bridging and mediating between the society and the other potential civic 
actors. However, in order not to be too ambitious when speaking of the context of Jordan in particular or the Arab context, this vision requires negotiations between the 'rigid' already existed institutions in different aspects. Therefore, the action plan or the envisioning processes responses to the current status quo that we are facing: the existing gap between architectural pedagogies and the civic society, and the current rigid policies that govern and police those educational and civic institutions in Amman. "One of the more serious failings of some so-called public art has been... to produce public spaces and objects that provide solutions - answers rather than questions" (Rendell, 2006: I). Therefore, it is important here to clarify that catalysing change within the highly political and neoliberal practices dominations context is about empowering to critique and questions rather than finding actual solutions. In pedagogical terms too, this means instead of the 'banking concept', telling others what to do, it is about enabling and empowering communities to question and re-think their spaces, needs, democratic and participation processes.

This study proposes potential civic pedagogical tactics that are strongly related to Arabic academics. The proposed tactics draws civic possibilities: provoking questioning of spaces, expand to work with the wider civic society and different social bodies and advocate and raise awareness about members of the public right to the city. In this way, This study could argue that critical pedagogy have the potential to become tactical to catalyse change, going beyond the banking concept to enabling and empowering models that acknowledges the role of what Darder et al. (2003) define it as 'a nexus of power relations' in translating and constructing knowledge.

\section{How architectural pedagogy is performed in Jordan?}

This section illustrates the ways in which architectural pedagogy is performed in Jordan and how civic they are. It also focuses on the specific opportunities and limitations that are presented in Jordan in particular and in the Arabic region context in general.

Generally, with no exception to the Arab world, educational systems are the essential responsibility of the state. BBC News has reported in 2008 that "The Arab education system is falling and needs urgent reforming", based on the World Bank report which manifested the lack of reforming within the educational sector which led to unprepared graduates for professions. Although Jordan and Kuwait were not identified as other countries in the region are actually suffering, there are regional challenges that Jordanian educational system is suffering from.

Jordan, the refugee heaven, has been hosting multiple waves of refugees for the past few decades. According to the Red Cross, 100,000 Palestinian refugees, as result from the first Arab-Israeli war in 1948, have moved to settle in Jordan (Ababsa, 2010; Zureik, 1996). The second waves of Palestinian refugees to Jordan figure was around 300,000, which was as a result of the Second Arab-Israeli war in 1967 (Daher, 20I I). The third wave of Palestinian refugees was in 199I from the gulf which was around 350,000. Iraqi refugees also started to arrive since the 199| till 2007, which estimated around 300,000 (ibid). Recently, I.265 million Syrian refugees have been displaced to Jordan since $20 \mathrm{II}$ (Jordan Times, 2016).

This in turn increases the demand on multiple resources including education. While the Jordanian governments accompanied with various non-governmental organisations (NGOs) are busy safeguarding access for all (nationals and refugees) to education. The 
quality of this education lacks its critical and civic content "the quality of education remains uneven and not competitive by international standards, particularly in poorer urban and rural areas" (USAID.gov, 20I6). The USAID (2016) report further labelled the Jordanian educational system as 'rigidly national' and highlighted the lack of welltrained teachers in 'public' schools in Jordan. Public schools here refer to schools under the public realm; which is funded and managed by the Jordanian governments. It is a well-known phenomenon that private schools in the Arabic region including Jordan offers a better-quality education, in comparison to the state public schools (Jordan Times, 20I4), leading to better opportunities in the future. Quarter of the Jordanians can afford and attends private schools (ibid). In other words, social inequalities are reproduced in our neoliberal region.

Architectural pedagogy in Jordan has an interesting history and geo-political Arabic regional relations. Spatial practitioners in Jordan used to travel to Egypt during the Ottoman Empire (1516- 1918). The first emerged schools of Architecture since 1820 'Mohandeskhana' in Cairo affiliated with Public Works followed the system of Paris Polytechnic (Abdel-Gawad, 1950). Following a westernised system illustrates the strong relations and ties between pedagogy and political agendas and events between Egypt and France (Sakr, 1993). This in turn has been manifested in the architectural educations and profession. Further Architectural French system schools emerged; such as Cairo University in 1935 followed by Alexandria University 194I (Salama and Amir, 2005). In the Levant region, only until the mid-1940s and 1960s Schools of Architecture started to emerge.

In terms of tracing the history of the Arabic architectural education, Salama and Amir (2005) highlighted how Architectural schools in the Arab world have been enforced, by official policy makers, to meet the international westernised criteria, norms and standards. They also emphasised how the economic boom in the gulf during the 1970s transformed architecture education practices within the whole Arabic region, shifting them towards American models (ibid). Replicating the westernised and the American models and specific ways, without critically engaging with our own issues with the specificity of our social, cultural and political context is a problem that still endures today. Furthermore, they outlined clearly that Arabic architectural education is based around three paradigmatic themes or trends during the past few decades: environmental-behaviour studies; a focus on sustainability and environmental consciousness; and digital and virtual practices.

This supports some of the findings of this research when explored and evaluated architectural curricula at nine public and private Architecture Schools during 2018 in Jordan. Although the nine curricula had a compulsory module called 'National Education', none of them had modules or programmes where students seem to work with the wider civic society participatory mechanisms. Five different academics from both public and private schools of architecture in Amman-Jordan were interviewed. The core discussions of the interviews focused on tracing any civic interventions towards spatial justice, collaborations with the wider society and exploring possibilities and opportunities for civic pedagogies.

Unfortunately, the majority, four out of five, focused on physical spatial practices rather than participatory mechanisms or civic responsibilities. An academic at a public university specified: 
"we try to tackle neo-liberalism in Amman city by assigning students to an urban project located near a gated community or business centre, such as the Abdali project, where the students can develop their skills to observe and analyse the impact on morphological layers of that area, focusing on the historical character of Amman city and whether the new developments are integrated within the existing fabric of the city. Here, students can develop some principles and recommendations to maintain the historical fabric of the city such as local brick and stone material instead of glass and steel structures" (Formal Interview I, 17/06/20I7).

However, these prompt questioning the role of future spatial practitioners' educators and architects: whether to produce forms and objects to be photographed or to work in human relations within the space and our everyday experiences. One academic, coming from an international university, who focused on the human dimensions: "we try to tackle social and spatial inequality through assigning students to design civic centres in the area between the East (poor) and the West (rich) of Amman. Students can therefore become aware of these inequalities in our society. They have to engage and speak with people in the area prior to their design proposal" (Formal Interview 4, 2l/06/2017).

Moreover, none of the nine Architecture curriculums nor the five academics indicated any relations to political relations modules and how does it impact directly the spatial production in our cities and our everyday experiences. Additionally, Hoteit (2016) states that these phenomena are regional in the Arab World, where architectural curricula are based on traditional approaches. However, separating architectural pedagogy from everyday life experiences could be an outcome of what Friere (1996) called it as 'the banking model of education', which represents students as passive and being told, from the teacher, the institutions or the state. Such knowledge transfer in Architectural terms focuses in good images and forms rather than critical approaches and civic relations. This study could response to argue that the more critical architectural pedagogies and practices are the less spatial.

It is fundamental to emphasise on my position as a researcher at the Sheffield School of Architecture (SSOA). As the subsequent section discusses three cases wherein civic pedagogical tactics were utilised. As this study intentions to explore, how such practices can become a vehicle which can be translated to the specific context of Amman. Translation processes here does not mean replicating or importing Western approaches to the context of Amman. Some notions and practices cannot be transferred directly, for instance, Western notions about democracy. As an alternative, such processes of translations require adopting and nesting to the specific social, political and cultural fabric. Although Salama and Amir (2005) highlighted the lack of regional-centric references and materials which they named this phenomena as unavoidable, it is important to adopt and nest this international knowledge in a way that becomes decolonising, avoiding the superior image of Westernised materials and knowledge, instead it should be considered as mutual and two-way of learning.

\section{Civic pedagogic tactics}

"Most Arab countries have suffered from the control of tyrannical totalitarian regimes, a far cry from democracy and freedom of expression. They also suffered from the dependency on Western countries and their guardianship. Most of the current political 
systems have flaws such as corruption and bureaucracy, which were either destroyed by the recent revolutions, or are on the verge of collapse. The entire Arab world is witnessing very complex developments... Architecture in the Arab society has reached a critical point which requires reconsideration of the way that it is approached" (Hoteit, 2016: 3).

Throughout critiquing the way which architecture pedagogy are performed in the Arabic region, and in particular in Jordan, revealed the urgency and need for more critical forms that are capable to bridge between academia and the society. The current existing architectural curricula in Jordan, after looking at nine different curricula (from both private and public universities, lacks participatory mechanisms and tends to be focused on westernised theories and practice. Furthermore, those curricula are not adjusted nor tailored to the political, social and economic specificity of the particular context of Amman and the Arab context.

This lead to address the main questions of this study: how can civic pedagogic tactics be introduced to the context of Amman? This study translates civic actions that have been drawn from intervening and mediating practices conducted by the researcher, as well as some practices that are capable of drawing some important and relevant lessons. As a result, a series of propositions and visions can be extracted for the future, advocating for the role of pedagogy in sustaining public space dynamics.

\section{'A school within the school' - how to negotiate with (to survive in?) 'rigid' institutions}

Civic involvement can be a challenge in some contexts, whether on institutional levels or individuals. Thus, tactics needs to have poetic and indirect characteristics to resist those challenges and limitations. Such tactics can be traced back within performative spatial practices in other geographical region and time frame; however, it can be extremely relevant to what we are facing today in the Arab world. For instance, the civic and performative tactics used by the young Romanian architects in the 1980s, Form-Trans-Inform, resisting the Ceausescu regime. The control of the regime went beyond the social structure of Romania towards political and educational institutions (Stratford et al., 2008). This in turn, has impacted Romanians' everyday experiences. The group, however, as a response, deployed performative and civic pedagogic tactics using poetic and indirect actions. One of the members explained:

"We were not engaged in a direct political critique - as protest or political demonstrations [...] but indirect, embedded in internal codes and hidden meanings shared by those that were able to read them. It was a resistance through alternative discourse, through alternative ways of thinking and doing, alternative life style" (Stratford et al., 2008: II5).

However, it is important to highlight the ways in which they tried to overcome and survive the challenges through fragmented and smaller 'pockets of resistance' (ibid). Together students and architects, at the Bucharest School of Architecture, the "Institutal de Arhitectura lon Mincu (IAIM)", have deployed a number of tactics collectively which has a deep solidarity between individuals within the group. Although the group had never been granted permissions officially by the school, academics, architects and students have managed to create a 'school within the school' in various 
forms such collective events, exhibitions, resistance art activities such as film screening (ibid).

It is important to look in-depth they ways of which they have managed to practice and deploy those activities. For instance, the series of exhibitions started with only twenty participants, from different backgrounds, 'the Space-Object' exhibition (ibid). Their next exhibition 'Space-Mirror' has been arranged four years after the first one, which had seventy participants from various backgrounds (ibid). Although the group has been terminated by the officials, it was visible and recognised by different individuals and groups.

The ways which the groups dealt with challenging context poetically makes the model very useful for rigid architectural educational institutions in the Jordanian context. The poetic civic tactics are able to offer powerful social tools in such contexts, enabling the various collective activities such as exhibitions, events, collective actions and film screenings that bridge people from different disciplines such as academics, artists, students and other individuals.

Therefore, such model has offered alternative knowledge in shaping an otherwise, alternative curriculum which responds the rigid institutions and its formal pedagogy challenges. These tactics can potentially be tailored and translated to other contexts. An example for such translations is the Atelier d'architecture autogérée (aaa), which was launched by Petrescu and Petcou in Paris since 2006, whom were members of FormTrans-Inform. The aaa has deployed urban tactics challenging citizens' access and neglected spaces. As Petrescu (2013) states: "Tactics have been ways for us to transgress, even if only temporarily and locally, laws and regulations, roles, professional boundaries and so on". They have used the co-produced ECObox as a mobile tool which are able to be transferred over time to other locations. The mobility of the tool allowed resistance to their current limitations and challenges.

Initiating negotiations with the current rigid institutions in the context of Amman requires translations for such tactics. After conducting informal interviews and workshops with academics and different social bodies representatives. The envisioning negotiations processes can potentially be initiated as the following: Initially, finding alliances which share the same civic responsibilities and values both within and outside the institutions, in order to create collective body that are able to face the challenges. Within the higher educational institutions, this can begin through arranging a research group to encourage and provoke other members to evolve. Afterwards, the research group can arrange various pockets of civic interventions. Although recognitions and visibility of such practice is very important for expansions on the city scale, this requires time and formal and informal agencies to be involved. Deploying research groups which can arrange civic interventions tactics can potentially initiate negotiations processes to the current rigid curriculum.

\section{Teaching Studios Otherwise: a week off the rigid curriculum}

Many scholars consider design studios as the spine of architectural education (Dutton, 1987, Salma, 1995), for its capability of constructing the future of architects and urban designer in the city. However, the typical traditional methodology of design studios could be considered limited to sketching, presenting and critiquing phases (Sultan, 2018). Therefore, other scholars have been proposing alternatives such as the "case 
method', which is borrowed from schools of law. In this approach, academics with students are able to generate alternative reflections using open-ended narratives (ibid). Another alternative is Wright (20II) suggestion to provoke students to acquire knowledge and skills through identifying problems and trying to find solutions throughout the design processes. The notion of live projects went beyond and extended these alternatives, through connecting students with their real world (real clients and real projects). Therefore, and in intellectual terms, this is the real 'learning by doing', enabling students to gain various skills and experiences outside the studio and the university borders.

A noticeable practical example of such radical design studio approaches can be witnessed at the Sheffield School of Architecture (SSOA). This section illustrates one example of such studios and reflects on the modules and the lessons that can be translated to the context of Amman. With Helen Stratford, I co-led a design Studio for MA in Architectural Design Masters students entitled 'Pseudo-Public Space: Public Space Does Not Exist!' in 2017-2018. We have encouraged and provoked students to test/practice various performative methodologies as tactics to challenge and re-think public spaces in different cities.

Significantly, the studio explored how cities are performed through the everyday actions. Throughout the studio, critical seminars, practices and reflections were employed to co-produce 'constructed situations' which has revealed an un-spoken and un-written norms, policies and knowledge about the existing spatial practices. Out of this knowledge, students have developed wider strategy and propositions that deemed public. While the first semester focused on critical discussions that resulted in performative interventions, constructed situations, for the UK context only, students were encouraged to translate the methodology in their home city. This has provided opportunities for exploring and testing the ways in which spaces are performed in very different political, cultural and social contexts, as well as adopting methodologies to suit and response to the specific context.

Overall, these processes have enabled students to test/practice/envision performative methodologies in various contexts, for instance, one student explored the ways in which Tiananmen Square is performed. His constructed situation was 'sunflower seeds' including hidden questions, as an appropriate tactics to the highly political control square. Although such performative interventions were envisioning resistance acts, students were able to imagine and tailer tactics poetically and gain insights for the ability of alternative practices to connect with the community and co-produce alternative spaces.

This proves the key role and potentials of pedagogies in sustaining public spaces dynamic. This example has illustrated how using performative (direct actions) methodology can initially be used in teaching design studios otherwise, alternative ways that could be translated to different contexts including Amman. Using performative methodology can also catalyse change and brige with the civic society. However, such translations need constant adoptions when traveling from context to another including the developments of performative interventions. Furthermore, such tactics in design studios can initiated within the context of Amman as "a week off" the studio. This can be the initial phase for going outside the university boundaries and connect with other civic bodies, providing opportunities for building alliances and mediate between the realm of academia, civic institutions and the wider society. The ultimate desire for such 
propositions is to enable students to engage with the wider society and their everyday life experiences, in order to catalyse change.

\section{Amman's Live project}

Live engaged projects as studios have become more popular in the UK and other western countries (Butterworth., 2013; Harriss and Widder, 2014). Although live projects have various forms, organisations and length, they all share their aim in connecting students with the wider community. In other words, they provoke the school of architecture to open up for civic interventions. Stone and Woof (2015) described it as transformative learning tools which connect theories in the realm of academia with 'real' practice. Therefore, dealing and collaborating with different actors (wider society, real clients, real projects), can potentially be used as a tool for sustaining public space dynamics, constructing relations between the academia and the wider society.

Significantly, Rulal Studio in the United State, which was launched by Mockbee and Ruth in 1992 was one of the earliest examples of live projects. The emphasis was on shifting the learning processes beyond the top-down structures of traditional learning, and from architect-client approaches:

"Live Projects develop the collaborative and participatory skills that are essential to future practice. Live Projects establish an awareness of the social responsibility of the architect and can empower students to produce work of exceptional quality that makes a difference to the communities they work with. Beyond the direct impact of the project on the communities involved, Live Projects also make a wider impact by enriching the student learning experience, developing design, management and enterprise skills and significantly increasing employability"

(Butterworth et al., 2013).

SSoA radical approaches and Butterworth's (2013) emphasised on the skills that goes beyond the realm of academia to focus on participatory and collaborative practices. Such skills and processes occur through steering up dialogue with other actors, which potentially allows empowering both students to engage, represents and response collaboratively with members of the public for the rethinking and the critical spatial production.

SSoA defines live project as:

"a relationship with an external client, a strong participatory nature and an emphasis on the processes of the project as well as its outcomes. It is a 'live' way of learning, practicing, and thinking about architecture... Working in response to the complexity of real-life situations enables students to experience the potential of research by design and to reflect simultaneously upon the processes, roles and effects of architecture... Live Projects give students the opportunity to explore an architecture that is both socially and environmentally sustainable... Through Live Projects, staff and students continually construct their own learning through action research and experience"

(Butterworth et al., 2013). 
These projects have the ability to integrate research, community and academia together. Therefore they have got transformative, civic and critical pedagogy nature. Introducing and envisioning live projects in Amman's schools of Architecture can potentially build a community that have civic responsibilities, resist capital and build resilience in its processes of evolving and expanding. An initial effort has been developed by the researcher in discussing such project with different actors within the context of Amman, including four local academics, from public and private universities, and social bodies in Amman. However, introducing such project requires time, agencies, activators and most importantly negotiations with the university.

On the other hand, envisioning live project in Amman can be defined as 'Performative design Live' project as a series of performative, transformative and relational processes that connect students with the 'real' world as education in direct relation with (different actors of) the City of Amman. Through these processes, students can gain the opportunity to critically engage with everyday lived experiences and various actors of the City of Amman. During this module, students explore architecture otherwise, playing with the dialectic relations between theory and practice, art and architecture, the spatial and social. This project uses both 'performative' and 'live', civic pedagogic, tools as a way of preparing students to become future professionals who engage with different actors and creative methods to practice architecture otherwise. This in turn allows them to produce alternative and critical knowledges and spaces. This can be introduced as a core design studio module for fourth year Architecture students at Schools of Architecture in Amman.

For instance, students can collaborate with different actors within the city, such as the theatre, artists, art institutions and the wider civic society, using various participatory and performative mechanisms to critically produce alternative spaces of dialogue, and develop propositions for the wider society. In a way it provides possible solutions for the wider society that the state might not be able to engage with.

\section{Discussion and Conclusion}

Exploring the ways which architectural pedagogy is performed in Jordan proved its urgent needs to reform and negotiate their rigid structure. However, there is a great potential to open up possibilities for educational institutions to have civic responsibilities and become the medium between the wider society and other institutional bodies, which potentially goes beyond producing objects to constructing relations.

The significant findings to emerge are the importance to navigate the future and initiate mediating processes and tactics which includes recruiting civic alliances. The ultimate desire for such processes is to build a community with various actors, including academics, civic institutions, NGOs and members of the publics, in Amman with civic pedagogical responsibilities. The hope for constructing such community is to critically co-produce alternative spaces that deem public, and build resistance and resilience to the emerging challenges.

The other practical efforts in envisioning civic pedagogical tactics, is drawn from radical approaches that has been developed at the Sheffield School of Architecture. In particular teaching studios otherwise as 'Pseudo Public Space, Public Space Does Not Exist!', Live collaborative projects and workshops. Furthermore, learning how the young Romanian architects have used poetic tactics. The three cases have helped in navigating 
the ways in which these methodologically can be tailored to Amman context to critique the spaces and produces alternative publicness.

The key themes that have emerged is that pedagogy within higher educational institutions have the potential to construct relations, situations and therefore can be the instrument to sustain the dynamic of public. Having argued that, such practice can be aligned with Rendell's (2006) critical practices which are associated with tactical interventional and transformative approaches to critique the social conditions and its boundaries. These proposed tactics should cross the rigid boundaries of physical architecture and includes collaborating with other institutional bodies and the wider society and take various forms such as live art, performative and site specific interventions and public participatory mechanisms.

Overall the study response to the ways in which architectural education is performed and proposes possibilities and opportunities for a set of poetic civic pedagogical tactics. These tactics are tailored to suit the specific context of Jordan to sustain public spaces dynamics. This research offers alternative visions that go beyond the objects towards inhabitancies' right to the city and catalyse change. The current status quo of how architecture pedagogy is performed in Amman revealed the urgency to call for poetic forms of resistance to become performative and civic pedagogic tactics within the official rigid institutions. Therefore, 'a school within the school' by the young Romanian architects in the 1980s has been employed to draw flexible and poetic ways to negotiate with those rigid institutions. They have offered approaches to build a resistance community bridging student in the realm of academia with architects, artists and urban activists. Moreover, teaching design studios otherwise and live project offer pedagogical paradigm to construct relations and situations, provokes the critical "co"-production of alternative knowledge and spaces that have civic responsibilities.

Therefore, architects and architectural educators within the Arabic region in particular should have a wider mission and re-thinking their roles towards the right to the city and its spaces and the civic production and awareness for those future practitioners. Such proposes encourages and advocates for engaging with various actors and agencies including the wider society with socio-political and economic relations with spaces.

\section{Acknowledgement}

This research paper is part of the submitted $\mathrm{PhD}$ thesis to the University of Sheffield entitled "Civic pedagogy and performative spatial practice to critique, reclaim, and produce public space in Amman" by the author in October 2019. I would like to thank Prof. Doina Petrescu and Dr. Krzysztof Nawratek who supervised, offered insight and expertise that greatly supported this research. 


\section{References}

Ababsa, M. (2010). The evolution of upgrading policies in Amman. Paper prepared for the Second International Conference on Sustainable Architecture and Urban Development: 12 - 14 July 2010. Institut français du Proche-Orient, IFPO.

Ababsa, M.(20I I). Social Disparities and Public Policies in Amman. In M. Ababsa and R. Daher (ed.), Les cahiers de I'IFPO: Vol. 6. Cities, urban practices and nation building in Jordan, in: Villes, pratiques urbaines et construction nationale en Jordanie. Beyrouth: Presses de l'ifpo, Pp. 205-23I.

Ababsa, M. (2013). Introduction. Citizenship and Urban Issues in Jordan, in: Villes, Pratiques Urbaines et Construction Nationale En Jordanie, Cahiers de l'Ifpo. Presses de l'Ifpo, Beyrouth, pp. 39-64.

Abdel-Gawad,T. (1950). Architecture of the 20th Century between Form and Content.ArchitectureMajalatu Al Imara in Egypt). 25 PP 67-72. (Translated from Arabic).

About Live Projects. Sheffield School of Architecture [WWW Document], n.d. URL http://www.liveprojects.org/about/2/ (accessed I.14.19).

Butterworth, C., Langfield, J., Hicklin, I., Brown, S. (20I3). SSoA:A Handbook for Live Projects. The University of Sheffield.

Care, L., Hicklin, I., Langfield, J. (2013). What is it like? at the University of Sheffield. United Kingdom.

Cauter de, L., de Roo, R. \& Vanhaesebrouck (eds.) (20I I). Art and Activism in the Age of Globalisation. Rotterdam: NAi Publishers.

Certeau, M. de (1988). The practice of everyday life. University of California Press, Berkeley, Calif.; London.

Daher, R. (2008). “Amman: Disguised Genealogy and Recent Urban Restructuring and Neoliberal Threats", in The Evolving Arab City: Tradition, Modernity \& Urban Development, Elsheshtawy, Yasser (Editor). London: Routledge: Taylor and Francis Group, pp. 37-68, 2008.

Daher, R. (20II). "Discourses of neoliberalism and disparities in the city landscape : Cranes, craters and an exclusive urbanity", in M. Ababsa and R. Daher (ed.), Cities, Urban Practices, and Nation Building in Jordan, Beirut, Institut Français du Proche-Orient, Pp. 273-296.

Darder,A., Baltodano, M. and Torres, R. (2003). (Eds) The Critical Pedagogy Reader. London: Routledge.

Dutton, T.A. (1987). Design and Studio Pedagogy. Journal of Architectural Education (1984-) 4I, 16-25.

Fethi, I., Mahadine, K. \& Salama,A. (1993). Toward Bridging the Gap Between Theory and Practice:The Status of Construction and Its Affiliated Courses in Arab Architectural Education Today. Open House International.Vol. (I8) 4. PP. II-I8.

Freire, P. (1996). Pedagogy of the oppressed. Revised edition edn. London: Hammondsworth Penguin.

Freire, P. (2000). Pedagogy of Freedom: Ethics, Democracy, and Civic Courage. Rowman \& Littlefield Publishers.

Harriss, H.,Widder, L. (20I4). Architecture live projects: pedagogy into practice. First edition. ed. Routledge Taylor \& Francis Group, London.

Hoteit, A. (2016). Architectural Education in the Arab World and lts Role in Facing the Contemporary Local and Regional Challenges. Canadian Social Science, 12 (7), I-7. DOI:http://dx.doi.org// 0.3968/8506

Jordan Times (2016). Population stands at around 9.5 million, including 2.9 million guests. Available online: [WWW Document], (2016). . Jordan Times. URL

http://www.jordantimes.com/news/local/population-stands-around-95-million-including29-million-guests (accessed 3.30.16). 
Kuttner, P.J. (2016). Hip-Hop Citizens:Arts-Based, Culturally Sustaining Civic Engagement Pedagogy. Harvard Educational Review 86, 527-555.

Lefebvre, $\mathrm{H},($ 199I). The production of space. Blackwell, Malden, MA.

MArch programmes | School of Architecture |The University of Sheffield. [WWW Document], n.d. URL https://www.sheffield.ac.uk/architecture/march (accessed 26.04.18).

Massey, D.B. (2005). For space. SAGE, London ;Thousand Oaks, Calif.

Massey, D.B. (2007). World city. Polity, Cambridge.

News.bbc.co.uk. (2008). BBC NEWS | World | Middle East | Arab education 'falling behind'. [online] Available at: http://news.bbc.co.uk/I/hi/world/middle_east/72276I0.stm [Accessed I 4 Jan. 2018].

Nicol, D. and Pilling, S. (2000). Changing architectural education:Toward a new professional role. London, UK: Spon Press.

Nicol, D., Pilling, S., Pilling, S. (2005). Changing Architectural Education :Towards a New Professionalism. Taylor \& Francis.

Petrescu, D., Petcou, C. (20I3). Tactics for a Transgressive Practice. Architectural Design. 83(6), 58-65. https://doi.org//0.1002/ad.1675.

Public vs. Private (20I4). [WWW Document]. Jordan Times. Available online: URL http://www.jordantimes.com/opinion/yusuf-mansur/public-vs-private-20I4 (accessed I.14.17).

Rendell, J. (2006). Art and architecture: a place between. IBTauris, London ; New York.

Said, E.W. (1994). Identity, Authority, and Freedom:The Potentate and the Traveler. Boundary 2, 2 I (3), $\mathrm{I}-18$.

Sakr, T. (1993). Early 20th Century Islamic Architecture in Cairo. Cairo:The American University Press.

Salama, A. M.A., O'Reilly,W., \& Noschis, K. (2002). Architectural Education Today: Cross-cultural Perspectives: Comportements.

Salama, A.,Amir,A. (2005). Paradigmatic trends in Arab architectural education: impacts and challenges, in: Paper Intended for Publication and Presentation at the International Congress of Architecture:The International Union of Architects-UIA: Istanbul.Turkey.

Salama, A. (1995). New Trends in Architectural Education: Designing the Design Studio, Tailored Text and Unlimited Potential Publishing, Raleigh, North.

Soja, E.W. (1980). The Socio-Spatial Dialectic. Annals of the Association of American Geographers 70(2), 207-225. https://doi.org/ I0. I I I I/j. I467-8306. I980.tb0 I308.x.

Stone, B., Woof, I. (20I5). Engaged Learning Sheffield. The University of Sheffield.

Stratford H, Petrescu D \& Petcou C (2008). Form-Trans-Inform: the 'poetic' resistance in architecture. arq:Architectural Research Quarterly, I2(02), I49-I 58.

USAID/Jordan Education Sector May (2016) | Documents | Jordan | U.S. Agency for International Development. [WWW Document], n.d. URL https://www.usaid.gov/jordan/documents/usaidjordan-education-sector-may-2016 (accessed 3.17.18).

Webster, H. (2004). Facilitating critically reflective learning: excavating the role of the design tutor in architectural education. Art, Design \& Communication in Higher Education, 2(3), I0I-I I I.

Webster, H. (2008). Architectural Education after Schön: Cracks, Blurs, Boundaries and Beyond. Journal for Education in the Built Environment, 3(2), 63-74.

Westheimer, J., Kahne, J. (2004). What Kind of Citizen? The Politics of Educating for Democracy. American Educational Research Journal 4I(2), 237-269.

Wink, J. (2000). Critical Pedagogy : Notes from the Real World. 2nd edn. New York: Longman.

Yaghi, A. (2017). Performative approaches to 'Reclaiming public space' in Amman. In: International Conference II: Reclaiming Public Spaces Within Metropolitan Areas. Amman:The German Jordanian University, I-I4. 
Yaghi, A. Petrescu, D., Nawratek, K., (2019). Performative Interventions to Re-Claim, Re-Define and Produce Public Space In Different Cultural And Political Contexts. Archnet-IJAR - International Journal of Architectural Research, 13(3), 7I8-735.

Zukin, C., Keeter, S., Andolina, M., Jenkins, K., Carpini, M.X.D. (2006). A New Engagement?: Political Participation, Civic Life, and the Changing American Citizen. Oxford University Press.

Zureik, E. (1996). Palestinian Refugees and the Peace Process. Washington, DC: Institute for Palestine Studies. 